\title{
Cement as a component of the multi-barrier system: radionuclide retention in cementitious environments
}

\author{
Xavier Gaona, Marcus Altmaier, Iuliia Androniuk, Nese Çevirim-Papaioannou, Michel Herm, \\ Luis Iglesias-Perez, Yongheum Jo, Volker Metz, Andrej Skerencak-Frech, Agost Tasi, and Horst Geckeis \\ Institute for Nuclear Waste Disposal (INE), Karlsruhe Institute of Technology (KIT), \\ Karlsruhe, 76344, Germany \\ Correspondence: Xavier Gaona (xavier.gaona@kit.edu)
}

Published: 10 November 2021

\begin{abstract}
Safety concepts regarding nuclear waste disposal in underground repositories generally rely on a combination of engineered and geological barriers, which minimize the potential release of radionuclides from the containment-providing rock zone or even their transport into the biosphere. Cementitious materials are used for conditioning of certain nuclear waste types, as components of waste containers and overpacks, as well as being constituents of structural materials at the interface between backfilling and host rock in some repository concepts. For instance, the preferred option for the disposal of high-level waste (HLW) in Belgium is based on the supercontainer design, which consists of a carbon steel overpack surrounded by a thick concrete buffer (Bel et al., 2006).

In the event of formation water interacting with cementitious materials, pore water solutions characterized by (highly) alkaline $\mathrm{pH}$ conditions will form. These boundary conditions define the chemical response of the radionuclides, but also influence the behaviour of neighbouring components of the multi-barrier system, e.g. bentonitic or argillaceous backfilling and host rock. Hardened cement paste or Sorel cement are considered to be main sorbing materials present in the near field of repositories for low- and intermediate-level waste (L/ILW). Hence, interactions of radionuclides with cementitious materials represent a very important mechanism retarding their mobility and potential migration from the near field (Wieland, 2014; Ochs et al., 2016). While the quantitative description of the sorption processes (usually in terms of sorption coefficients, i.e. $K_{d}$ values) is a key input in the safety analysis of nuclear waste repositories, detailed mechanistic analysis and understanding of sorption phenomena provide additional scientific arguments and important process understanding, and thus enhance both the quality of safety arguments and the overall confidence in the safety assessment process.

Research at KIT-INE dedicated to the interaction of cementitious materials with radionuclides is conducted in the context of different repository concepts, including clay (low- and high-ionic strength conditions), crystalline rock or rock salt. Experimental and theoretical studies are performed within the framework of national (GRAZ, BMWi) and international (CEBAMA and EURAD-CORI, EU Horizon 2020 Programme) projects, extending to third-party projects with several waste management organizations in Europe, e.g. SKB (Sweden), ONDRAF-NIRAS (Belgium) or BGE (Germany). The combination of classical experimental (wet chemistry) methods, advanced spectroscopic techniques and theoretical calculations provides both an accurate quantitative evaluation and a fundamental understanding of the sorption processes. Examples of recent studies at KIT-INE on radionuclide behaviour in cementitious systems in the context of both L/ILW and HLW will be presented in this contribution to explain methodologies, scientific approaches and results. The present state of knowledge as well as main remaining uncertainties affecting the retention processes of radionuclides in cementitious environments under different conditions will be critically discussed, also in view of current international research activities and repository projects.
\end{abstract}

Kurzfassung. Die Sicherheitskonzepte für die Entsorgung nuklearer Abfälle in unterirdischen Endlagern beruhen in der Regel auf einer Kombination aus technischen und geologischen Barrieren, welche die potenzielle Freisetzung von Radionukliden aus der einschlusswirksamen Gesteinszone oder sogar deren Transport 
in die Biosphäre möglichst geringhalten. Zementartige Materialien werden in einigen Endlagerkonzepten für die Konditionierung bestimmter nuklearer Abfallarten, als Komponenten von Abfallcontainern und für Umverpackungen („Overpacks“) sowie als Bestandteil des Konstruktionsmaterials an der Grenzfläche zwischen Verfüllung und Wirtsgestein verwendet. Die bevorzugte Option für die Entsorgung hochaktiver Abfälle (HLW) in Belgien basiert beispielsweise auf dem Supercontainerkonzept, das aus einem „Overpack“ aus unlegiertem Stahl besteht, umhüllt von einem dicken Betonpuffer (Bel et al., 2006).

Im Falle einer Wechselwirkung von Formationswasser mit zementhaltigen Materialien bilden sich Porenwasserlösungen, die durch (stark) alkalische $\mathrm{pH}$-Bedingungen gekennzeichnet sind. Diese Randbedingungen bestimmen die chemische Reaktion der Radionuklide, beeinflussen aber auch das Verhalten benachbarter Komponenten des Multibarrierensystems, z. B. der Bentonit- oder Tonverfüllung und des Wirtgesteins. Ausgehärtete Zementpaste oder Sorelzement gelten als die wichtigsten sorbierenden Materialien im Nahfeld von Endlagern für schwach- und mittelradioaktive Abfälle (LILW). Daher stellen die Wechselwirkungen von Radionukliden mit zementartigen Materialien einen sehr wichtigen Mechanismus dar, der ihre Mobilität und potenzielle Migration aus dem Nahfeld verzögert (Wieland, 2014; Ochs et al., 2016). Während die quantitative Beschreibung der Sorptionsprozesse (in der Regel in Form von Sorptionskoeffizienten, d.h. $K_{d}$-Werten) ein entscheidendes Element bei der Sicherheitsanalyse von Endlagern für nukleare Abfälle ist, liefern die detaillierte mechanistische Analyse und das Verständnis der Sorptionsphänomene zusätzliche wissenschaftliche Argumente und ein wichtiges Prozessverständnis und erhöhen somit sowohl die Qualität der Sicherheitsargumente als auch das allgemeine Vertrauen in den Prozess der Sicherheitsbewertung.

Die Forschung am KIT-INE, die sich mit der Wechselwirkung von zementartigen Materialien mit Radionukliden befasst, wird im Zusammenhang verschiedener Endlagerkonzepte durchgeführt, darunter Ton (niedrige und hohe Ionenstärke), kristallines Gestein oder Steinsalz. Experimentelle und theoretische Studien werden im Rahmen von nationalen (GRAZ, BMWi) und internationalen (CEBAMA und EURAD-CORI, EU Horizon 2020 Programm) Projekten durchgeführt, bis hin zu Drittmittelprojekten mit verschiedenen Entsorgungsinstitutionen in Europa, z. B. SKB (Schweden), ONDRAF-NIRAS (Belgien) oder der BGE (Deutschland). Die Kombination von klassischen experimentellen (nasschemischen) Methoden, fortgeschrittenen spektroskopischen Techniken und theoretischen Berechnungen ermöglicht sowohl eine genaue quantitative Bewertung als auch ein grundlegendes Verständnis der Sorptionsprozesse. Anhand von Beispielen aktueller Studien am KIT-INE zum Verhalten von Radionukliden in zement-basierten Systemen im Kontext von LILW und HLW werden in diesem Beitrag Methoden, wissenschaftliche Ansätze und Ergebnisse erläutert. Der gegenwärtige Wissensstand sowie die wichtigsten verbleibenden Unsicherheiten, die die Rückhalteprozesse von Radionukliden in zement-basierten Umgebungen unter verschiedenen Bedingungen beeinflussen, werden kritisch diskutiert, auch im Hinblick auf aktuelle internationale Forschungsaktivitäten und Endlagerprojekte.

\section{References}

Bel, J. J. P., Wickham, S. M., and Gens, R. M. F.: Development of the Supercontainer Design for Deep Geological Disposal of High-Level Heat Emitting Radioactive Waste in Belgium, MRS Online Proceedings Library, 932, 1221, https://doi.org/10.1557/PROC-932-122.1, 2006.
Ochs, M., Dirk, M., and Wang, L.: Radionuclide and metal sorption on cement and concrete, Springer, Switzerland, https://doi.org/10.1007/978-3-319-23651-3, 2016.

Wieland, E.: Sorption database for the cementitious near field of L/ILW and ILW repositories for provisional safety analyses for SGT-E2, Nagra Technical Report 14-08, Paul Scherrer Institut, Villigen, Switzerland, 2014. 